\title{
MECHANISMS AND SIGNIFICANCE OF FUNGICIDE RESISTANCE ${ }^{\dagger}$
}

\author{
Holger B. Deising ${ }^{1 *}$; Sven Reimann ${ }^{1 \S}$; Sérgio F. Pascholati²
}

${ }^{1}$ Martin-Luther-University, Faculty of Natural Sciences III, Institute of Agricultural and Nutritional Sciences, Phytopathology and Plant Protection, Halle (Saale), Germany; ${ }^{2}$ Escola Superior de Agricultura Luiz de Queiroz, Universidade de São Paulo, Setor Fitopatologia, Piracicaba, SP, Brasil.

Submitted: May 04, 2007; Returned to authors for corrections: February 19, 2008; Approved: March 18, 2008.

\begin{abstract}
In this review article, we show that occurrence of fungicide resistance is one of the most important issues in modern agriculture. Fungicide resistance may be due to mutations of genes encoding fungicide targets (qualitative fungicide resistance) or to different mechanisms that are induced by sub-lethal fungicide stress. These mechanisms result in different and varying levels of resistance (quantitative fungicide resistance). We discuss whether or not extensive use of fungicides in agricultural environments is related to the occurrence of fungicide resistance in clinical environments. Furthermore, we provide recommendations of how development of fungicide resistant pathogen populations may be prevented or delayed.
\end{abstract}

Key-words: Citrus black spot disease, disease management, fungicide resistance, efflux transporters, wheat $\tan$ spot disease

\section{INTRODUCTION}

Development of human civilization has been closely linked to cultivation of crops, and plant diseases have been a concern to mankind probably since plants were cultivated more than 10,000 years ago (12). Biblical accounts, at about $1870 \mathrm{BC}$, and records of the early Greek and Roman literature dating from approximately $500 \mathrm{BC}$, indicate that severe epidemics threatened crops and, as a consequence, people of that time (see also 27). In the Roman world, ceremonial appeasement of Robigus, the God for cereals, appeared to offer the only hope of preventing crop failure. At the end of the $19^{\text {th }}$ and the beginning of the $20^{\text {th }}$ century, chemical plant protection schemes were developed, with copper and sulfur as antifungal agents to control downy and powdery mildews. These early treatments led to the establishment of a multi-billion dollar industry that has developed efficient modern fungicides belonging to various chemical classes, differing in their mode of action against pathogens and characteristics of uptake and distribution within the plant.

In the last decades, numerous cases of fungicide resistance have occurred world-wide, leading to losses of entire fungicide classes in several cases (Tab. 1) (12). At the onset of chemical plant protection, fungicides with several targets in the fungal cell (so called multi-side inhibitors) were released to the market, irrespective of their toxicity to humans and other organisms. For example, organomercurials were used to control seed-born pathogens such as Pyrenophora avenae or $P$. graminearum, causing leave stripe disease in oats and barley. Organomercurials were used in Europe, beginning from the mid $1920 \mathrm{es}$, and it took some 40 years until first reports about loss of fungicide efficacy were published. The development of systemic fungicides was considered as a hallmark in chemical plant protection, as not only those parts of the plant were protected that had been sprayed directly. Systemic fungicides are taken up by the plant and are

*Corresponding Author. Mailing address: Martin-Luther-University, Faculty of Natural Sciences III, Institute of Agricultural and Nutritional Sciences, Phytopathology and Plant Protection, D-06099 Halle (Saale), Germany; Phone +49-345-5522660; Fax +49-345-5527120, E-mail: holger.deising@landw.uni-halle.de

$\S$ present address: Thüringer Lehr-, Prüf- und Versuchsgut GmbH, Am Feldschlößchen 9, 99439 Buttelstedt, Germany.

$\dagger$ The data reported here have in part been presented orally at the XXX. Congresso Paulista de Fitopatologia, Jaboticabal, SP, February 13-15, 2007. 
subsequently distributed within the entire plant, protecting also newly formed tissues. Thus, these fungicides were curative and allowed to control pathogens after infection had occurred. With these chemicals, fungi living in the xylem (tracheomycoses) became controllable for the first time. Highly specific modern fungicides were developed that blocked only one target in the pathogen (monospecific fungicides or single-site inhibitors). Examples for single-site inhibitors are the benzimidazoles, phenylamides and strobilurins, which were released to the market in the late 1970es and in the mid 1990es. Shockingly, it took only two years of intensive use of benzimidazoles for resistance to develop in the apple scab fungus Venturia inaequalis and in the polyphageous grey mold fungus Botrytis cinerea. Also in other single-site inhibitors such as the phenylamides and the strobilurins, which were much later released, resistant strains occurred within two years after the compounds were introduced to the market and widely used (see below). In contrast, fungicides with more than one target in the fungal cell, e.g. the morpholines, which inhibit sterol biosynthesis by inhibiting $\Delta^{8}-\Delta^{7}$ isomerase as well as $\Delta^{14}$ reductase activity $(25,30,40)$, have been used for more than 30 years before resistant isolates have been found (Table 1). These data clearly argue against putting high priority on development of single target fungicides.

\section{Brief case reports on failure of fungicide treatments in post- harvest disease control}

Particularly in tropical agriculture protection of products after harvest is an important issue. On a world-wide scale, Brazil is the third biggest producer of fruits, with an annual production equivalent to approx. $35-37$ million tons $(3,4)$. Losses of up to $30-40 \%$ have been reported (4), indicating that post-harvest disease protection strategies are urgently needed, and introduction of fungicides could contribute to more efficient disease control.

Table 1: Occurrence of resistance against fungicides of different classes. After Hewitt (22), modified.

\begin{tabular}{|c|c|c|c|c|}
\hline $\begin{array}{l}\text { Fungicide } \\
\text { class }\end{array}$ & $\begin{array}{l}\text { number of } \\
\text { targets }\end{array}$ & $\begin{array}{l}\text { first } \\
\text { report }\end{array}$ & $\begin{array}{l}\text { years until } \\
\text { of resistance }\end{array}$ & $\begin{array}{l}\text { pathogen } \\
\text { of resistance }\end{array}$ \\
\hline organomercurials & many & 1964 & 40 & Pyrenophora avenae \\
\hline benzimidazoles & 1 & 1970 & 2 & $\begin{array}{l}\text { Venturia inaequalis, } \\
\text { Botrytis cinerea }\end{array}$ \\
\hline phenylamides & 1 & 1980 & 2 & $\begin{array}{c}\text { Phytophthora infestans, } \\
\text { Plasmopara viticola }\end{array}$ \\
\hline dicarboximides & 1 & 1982 & 5 & Botrytis cinerea \\
\hline DMIs & 1 & 1982 & 4 & Blumeria graminis \\
\hline carboxanilides & 1 & 1986 & 14 & Ustilago nuda \\
\hline morpholines & 2 & 1994 & 34 & Blumeria graminis \\
\hline strobilurins & 1 & 1998 & 2 & Blumeria graminis \\
\hline
\end{tabular}

In citrus, most significant economical losses are due to infection by Guignardia citricarpa, the causal agent of citrus black spot disease, the fruit rot fungus Penicillium digitatum and the anthracnose fungus Colletotrichum gloeosporioides. Application of imidazole fungicides such as imazalil has been recommended to control postharvest diseases. To address the question of in vitro and in vivo efficacies of DMIs, detailed studies with G. citricarpa have been performed (Fig. 1). In vitro growth assays indicated that no complete control was achieved by imazalil, even at concentrations as high as 200 ppm (Figs. 1a, b). Treatment of fruits with this fungicide basically failed to yield any effect. Also thiabendazole applied at the recommended rate failed to control occurrence of black spot symptoms (Figs. 1c, d). Similar results were found with other fruit pathogens such as $P$. digitatum and $C$. gloeosporioides (54). Rodrigues (42) reported on isolates of $G$. citricarpa that showedfull sensitivity to the strobilurin fungicide piraclostrobin, but severely reduced sensitivity to carbendazim, as detected by radial growth assays.

In a review, Forcelini et al. (18) list cases of resistance against different benzimidazoles, phenylamides and sterol biosynthesis inhibitors in several different pathogenic fungi in Brazil. These authors clearly indicate that fungicide resistance is an issue of increasing importance not only in fruit pathogens in Brazil.

\section{Qualitative and quantitative fungicide resistance}

The mechanisms conferring fungicide resistance, however, may differ, and the terms "qualitative resistance" and "quantitative resistance" have been coined to indicate these differences (Fig. 2). Qualitative resistance is mutation-based. Mutations may be introduced by UV irradiation, which is of particular importance in wind-borne non-pigmented spores such as conidia of powdery mildew fungi. If a gene encoding the target protein is mutated, so that an amino acid required for binding of the fungicide is exchanged, inhibition of the protein does no longer occur and fungicide treatments fail (Fig. 2a). In this case, even if very high fungicide concentrations are used, resistant individuals are not affected and survive the treatment. Few wildtype individuals may also survive the treatment, and both, fungicide-resistant mutant and sensitive wildtype propagules recover. Subsequent applications of the same fungicide constantly select for mutants, so that eventually the wildtype individuals disappear and the population consists of fungicide-resistant mutants only (Fig. 2a). During the selection process, only full sensitivity or full resistance is observed at the level of individuals; phenotypes with intermediate resistance do not occur. The 

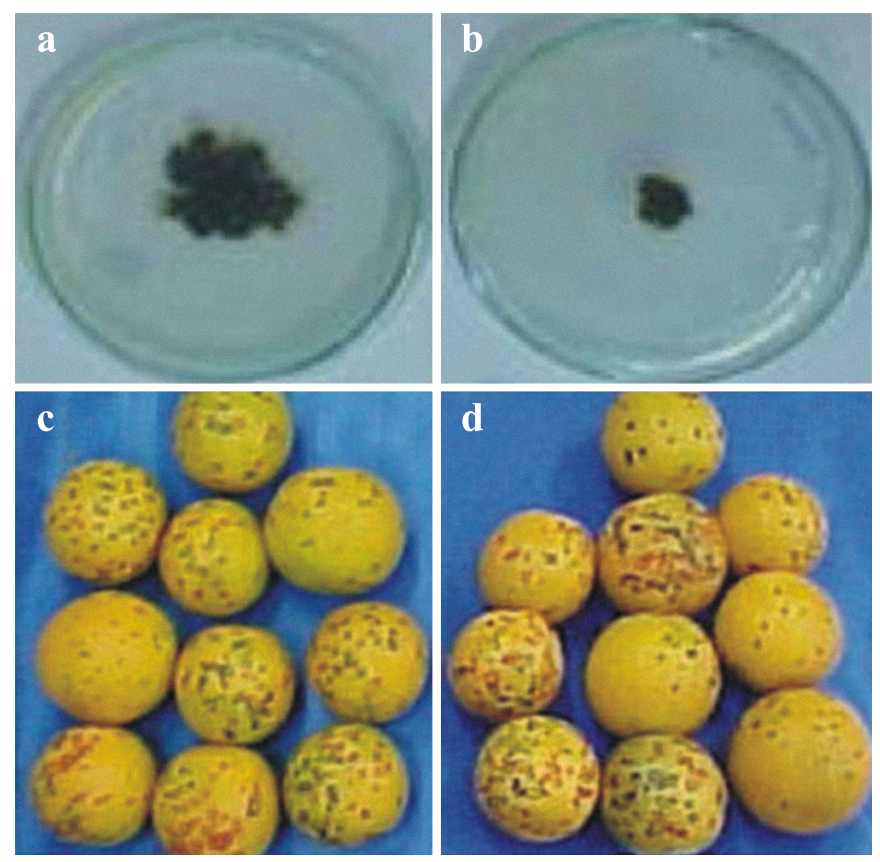

Figure 1: Efficacy of sterol biosynthesis inhibitor fungicides in in vitro and in vivo against the causal agent of citrus black spot disease, Guignardia citricarpa. Growth on control PDA plates without fungicide (Fig. 1a) and on plates containing 200 ppm imazalil (Fig. 1b) indicated that G. citricarpa can not be completely controlled, even at high concentrations of this fungicide. Accordingly, infection assays on non-treated orange fruits (Citrus sinensis var. Valência) (Fig. 1c) and fruits treated with thiabendazole at recommended concentrations (5 ppm) (Fig. 1d) indicated failure of fungicide treatment. Data from Toffano (54).

speed of the selection depends on the biology of the pathogen (for example duration of the reproduction cycle) as well as the number of fungicide applications. Mutation-based fungicide resistance is inheritable, and the progeny is able to develop in the presence of the particular fungicide. Interestingly, often no significant loss of fitness or virulence occurs in resistant populations $(1,8,31,50)$.

The single-site inhibitor benomyl was introduced to the market as the first systemic fungicide in 1967. The benzimidazole derivative binds to $\beta$-tubulin and therefore prevents cytoskeleton-dependent cellular transport processes, including chromosome transport and cell division. Highly conserved amino acids of $\beta$-tubulin are involved in fungicide binding, and in several plant pathogenic fungi like Venturia, Botrytis, Monilia and Penicillium species specific amino acid exchanges resulted in reduced binding of and resistance to carbendazim, which is the fungicidal compound intracellularly derived from benomyl
(10, and literature therein). As the amino acids involved in fungicide binding are highly conserved in most fungi $(10,48)$, mutation-based benomyl resistance involved the same amino acid exchanges in various fungi belonging to different taxa. Only two years after the introduction of benomyl, powdery mildew of cucurbits in New York state was the first to be reported as resistant to this fungicide (46), and since then many other powdery mildew fungi have developed resistance against this fungicide class (14).

Likewise, in 1998, after only two years of extensive application of strobilurins over large areas, qualitative resistance had occurred (2,29). Mutations mediating a G143A- or a F129L exchange lead to complete loss or drastic reduction of fungicide efficacies $(26,31)$. Single spore isolates of the apple powdery mildew Podosphaera leucotricha collected from commercial orchards were all heteroplasmic with respect to their mitochondrial cytochrome $b$ gene and differed in strobilurin sensitivity. Semi-quantitative polymerase chain reactions and cleaved amplified polymorphic sequences analyses suggested that the portion of mitochondria carrying the G143A exchange governed strobilurin resistance. Importantly, even those isolates that had been kept under defined conditions in the absence of fungicides had maintained cytochrome $b$ heteroplasmy and showed increased levels of strobilurin resistance (31). Regular treatment with strobilurins as solo-fungicides in the field will lead to selection of resistant mutants, with the fungicide acting as the selecting agent. It should be noticed, however, that in cereal rusts (Puccinia spp.) and in the barley and rye pathogen Rhynchosporium secalis strobilurin resistance has not been found, in spite of frequent applications of this fungicide over several years. The fact that mutation-based strobilurin resistance did not occur in these fungi is due to the cytochrome $\mathrm{b}$ gene structure. In these pathogens, codon 143 is at an intron border, and G143A mutations result in non-recognition of the intron border, failure in mRNA processing, and in expression of a non-functional cytochrome $b$ protein. Non-functional mitochondrial electron transport chains will result in nonviability of the mutated pathogen, and strobilurin-resistant G143A mutants can not occur in these fungi.

Several different mechanisms may lead to quantitative fungicide resistance. In most cases this type of resistance is mediated by keeping the intracellular fungicide concentration low. Mechanisms keeping the intracellular fungicide concentration below a critical threshold include synthesis of efflux transporters that secrete drug molecules to the extracellular space (Figs. 2b, 3), modifications of plasma membranes causing reduced fungicide permeability, or by synthesis of enzymes that degrade fungicide molecules $(13,24,32)$. Alternatively, overexpression of the gene encoding the fungicide target or utilization of alternative metabolic pathways has been reported $(28,34,45,52,57,58)$. In general, populations consist of individuals with more or less pronounced levels of tolerance to fungicides 


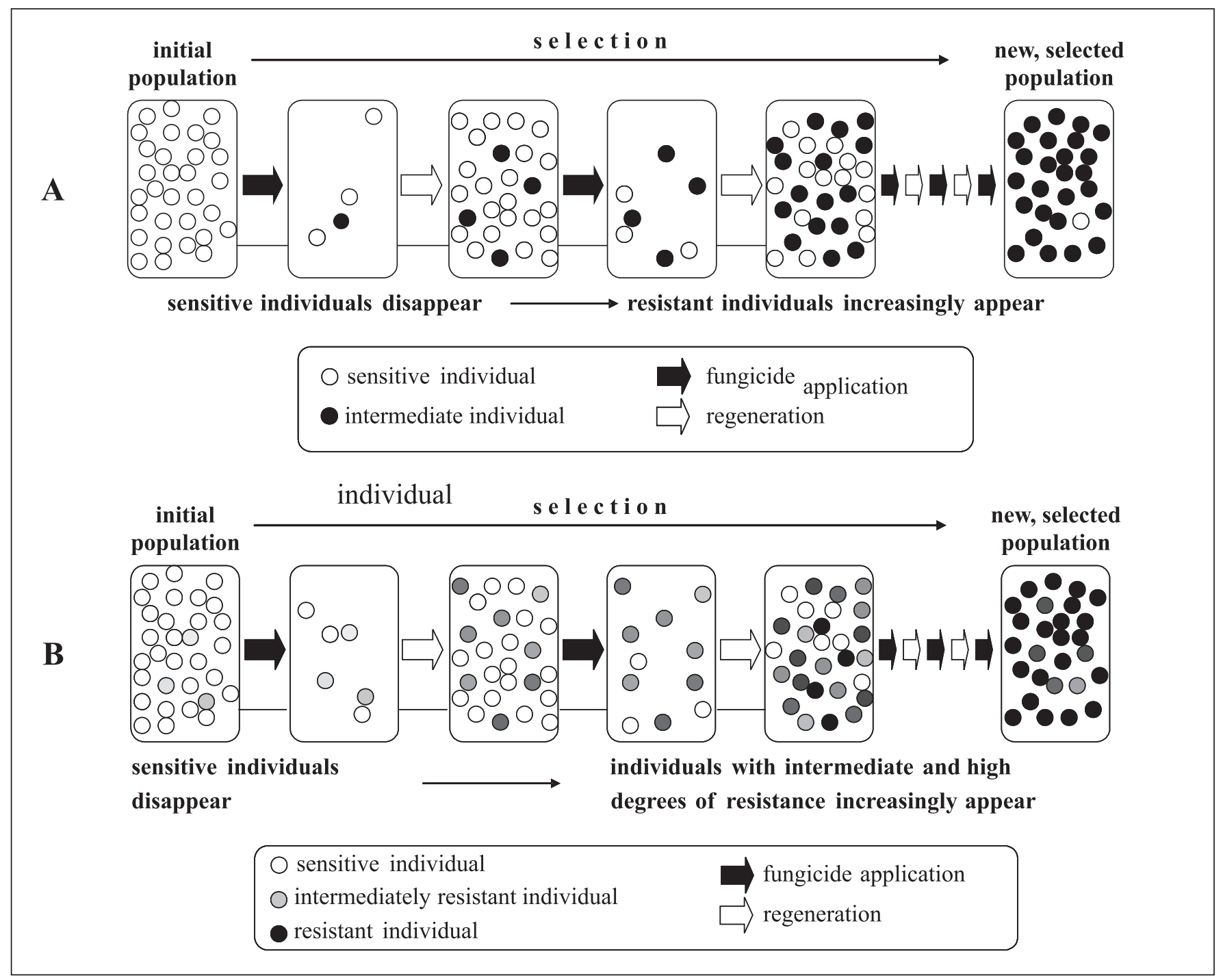

Figure 2: Development of fungicide resistance is a selection process, with the fungicide as the selecting agent. In qualitative resistance (Fig. 2a), mutation-based insensitive mutants are selected, and strains are either sensitive or resistant to the drug. In quantitative resistance (Fig. 2b) individuals that express genes leading to reduced fungicide sensitivity, are more likely to survive a drug treatment. Sub-lethal fungicide stress leads to further induction of genes that help resisting subsequent drug treatments. As a consequence the population is shifted to increasing resistance, and increasing numbers of individuals with higher degrees of resistance are found. For details, see text. After Hewitt (22), modified.

(at this level, using the term fungicide resistance is not appropriate), which is due to the fact that different mechanisms conferring tolerance are active at different levels. If fungicide treatments are performed, the tolerant individuals are likely to survive, and, in addition, sub-lethal fungicide stress will stimulate synthesis of efflux transporters, drug-degrading enzymes etc. (Fig. 2b). Thus, repeated fungicide treatments will shift a fungal population, and individuals with varying and over time increasing levels of resistance can be found until eventually the entire population consists of almost completely resistant individuals.

In the past, it became clear that qualitative, mutation-based fungicide resistance affects the performance of a fungicide in the field drastically. In spite of the fact that quantitative fungicide resistance is of extreme relevance in medicine (57), the drastic effect of mutation-based resistance made many plant pathologists believe that quantitative resistance is of minor importance in agriculture. However, during the last decade(s) 


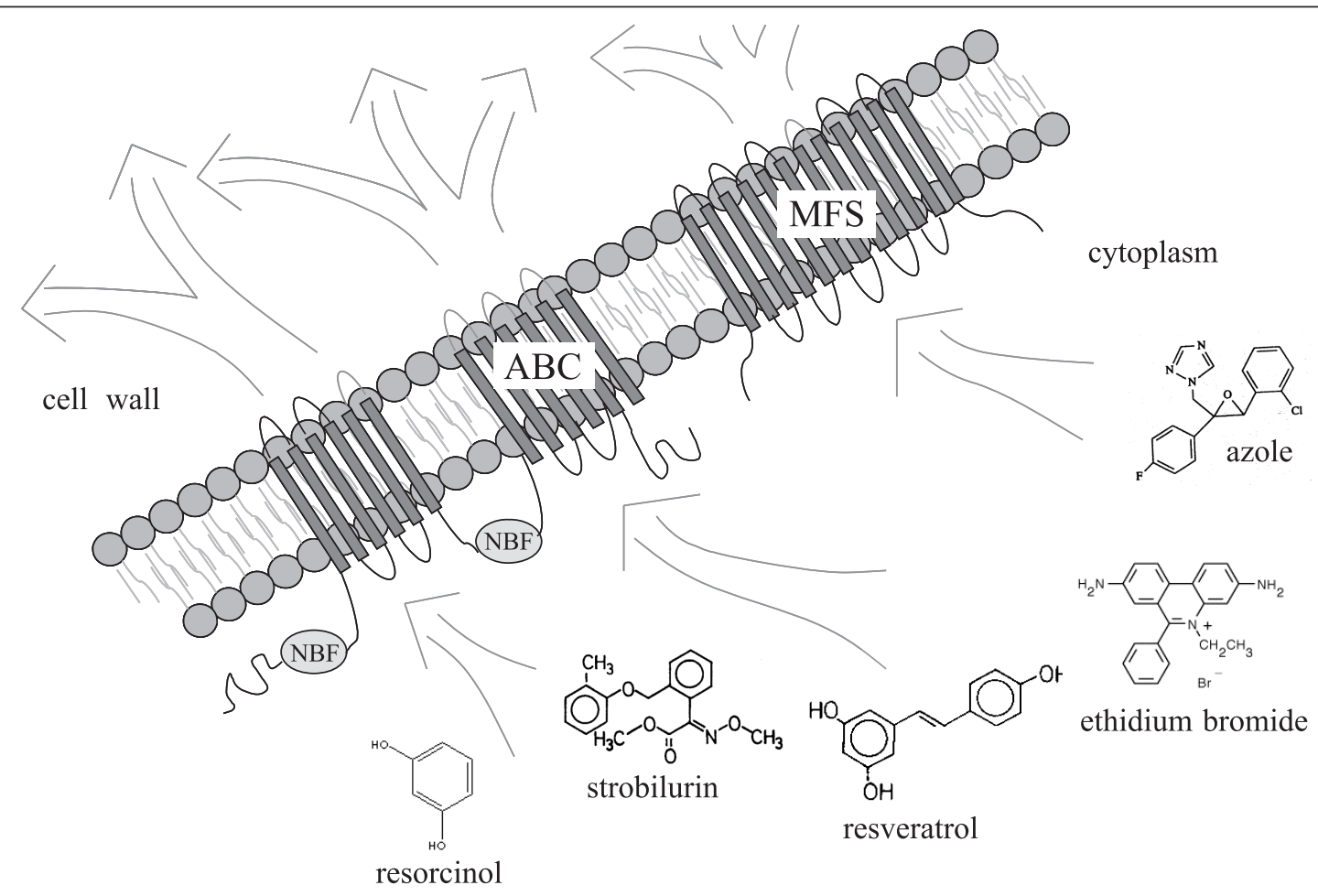

Figure 3: Diagram of a fungal ABC- and an MFS-transporter. The $\mathrm{ABC}$ transporter consists of two repeats of a nucleotide binding domain (NBF) and six trans-membrane domains; the MSF transporter has 12 trans-membrane domains. The membrane efflux pumps can transport structurally diverse molecules such as strobilurin and azole fungicides, the fluorescent dye ethidium bromide, and the plant defense compounds resveratrol and resorcinol. After Del Sorbo et al. (13), modified.

efflux transporters have been investigated in some detail, and a sound body of literature now indicates that these transporters represent an important mechanism of establishing quantitative fungicide resistance in plant pathogenic fungi.

\section{Efflux transporters allow fungi to grow in the presence of fungicides}

In bacteria efflux transporters have since long been known to confer multidrug resistance, and excellent reviews on this issue exist (35). In fungi efflux systems have evolved to confer resistance against naturally occurring toxic substances, e.g. phytoalexins or phytoanticipins formed by plants as a response to pathogen attack $(16,20,51)$. It is thus not surprising that these transporters also confer fungicide resistance (1113). Two families of plasma membrane-localized efflux transporters are known to be involved in secretion of toxicants, i.e. ATP-Binding Cassette (ABC) transporters and the Major

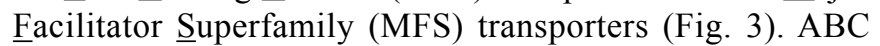
transporters utilize the energy from hydrolysis of ATP for transporting different and structurally quite diverse substrates against a concentration gradient across the plasma membrane.
MFS transporters, however, are unable to hydrolyze ATP and use the proton motive force to facilitate the transport not only of toxicants, but also of sugars, peptides and ions. More than 350 uni-, sym- and antiporters are known to belong to this superfamily $(13,38)$.

$\mathrm{ABC}$ transporters belong to a large and rapidly growing efflux pump superfamily (44). They possess a highly conserved $\mathrm{ABC}$ module, displaying the Walker ${ }_{\mathrm{A}}$ and Walker $_{\mathrm{B}}$ motifs (56), which are typically found in all proteins requiring ATP. In addition to the Walker motifs, $\mathrm{ABC}$ modules show a short, highly conserved LSGGQ consensus sequence, known as the linker peptide or ATP signature. The major difference between the various $\mathrm{ABC}$ systems is related to the polarity of transport. Transporters relevant for fungicide insensitivity are exclusively members of the export pumps, classified as ABC-A transporters (44). Even in the genome of the simple model fungus Saccharomyces cerevisiae 29 genes encoding ABC transporters exist (53), and one may well speculate that in comparison to $S$. cerevisiae, these transporters may be of more importance to plant pathogenic fungi that have to cope with toxic plant compounds or fungicides. 
As $\mathrm{ABC}$ transporters export substrates belonging to different chemical classes, they are thought to be of particular importance in adaptation of pathogenic fungi to various fungicides (13). As a matter of fact, the $\mathrm{ABC}$ transporter gene $A B C 1$ of the rice blast fungus $M$. grisea (55) is strongly induced by the rice phytoalexin sakuranetin and by azole fungicides. An $A B C 1$ deficient mutant penetrates the rice epidermis normally but died soon thereafter. As the mutant did not show increased sensitivity to sakuranetin or various fungicides, the exact role of this transporter remained unclear. Five ABC transporter genes of the wheat pathogen Mycosphaerella graminicola, designated MgAtr 1 to $M g A t r 5$, have been analysed in detail by Maarten deWaard and by his co-workers of the University of Wageningen, The Netherlands. Transformants of $M$. graminicola in which individual $\mathrm{ABC}$ transporter genes were deleted or disrupted did not exhibit clear-cut phenotypes, probably due to the functional redundancy of transporters with overlapping substrate specificity. However, MgAtr 5 deletion mutants showed increased sensitivity to the putative wheat defense compound resorcinol and to the grape phytoalexin resveratrol, suggesting a role for this transporter in protecting the fungus against plant defense compounds (59). Complementation of $S$. cerevisiae mutants with the ABC transporter genes from M. graminicola showed that all the genes tested encode proteins that provide protection against chemically unrelated compounds. The substrate range of the transporters expressed in yeast included fungicides, plant metabolites, antibiotics, and the Fusarium graminearum mycotoxin diacetoxyscirpenol. Taken together, the study by deWaard et al. showed that $\mathrm{ABC}$ transporters of $M$. graminicola play a role in protection against toxic compounds of natural and artificial origin $(11,59)$.

When isolates of Pyrenophora tritici-repentis, the causal agent of wheat tan spot, were allowed to adapt to strobilurin concentrations as low as 1,5 or $10 \mathrm{ppm}$, they were able to grow on plates containing $50 \mathrm{ppm}$ of this fungicide. The fact that growth of isolates on high fungicide doses depended on their previous adaptation level indicates that quantitative resistance had developed, and that mechanisms allowing the fungus to cope with the fungicide are activated to a different extent (Fig. 4A). In accordance with the fact that efflux pumps show broad substrate specificity, not only isolates adapted to strobilurins, but also those adapted to azole fungicides can also grow on plates containing high strobilurin concentrations (cross resistance) (Fig. 4B). Due to their broad substrate specificity, the activity of the transporters can be visualized by using fluorescent dyes such as ethidium bromide or Hoechst 33342 . This simple microscopic evaluation of hyphae allows assessing the efflux pump-mediated state of fungicide resistance (41). In strains that had not been adapted and were thus sensitive to fungicides, the dye invaded the hyphae and nuclear fluorescence occurred. When hyphae had been allowed to adapt to fungicides, efflux transporters were synthesized and located to the plasma membrane, and their activity resulted in strong cell wall / plasma membrane fluorescence. Fungicide-adapted (resistant) isolates were not only able to grow on artificial substrata amended with fungicides, but could also infect plants treated with fungicides at levels above recommended field concentrations. Importantly, application of the hydroxyflavone derivative 2-(4-ethoxy-phenyl)-chromen-4-one, a potent inhibitor of energy-dependent fungicide efflux transporters in P. triticirepentis, in combination with fungicides shifted fungicide resistant $P$. tritici-repentis isolates back to normal sensitivity levels and prevented infection of wheat leaves (41). These results clearly demonstrated the role of efflux transporters in fungicide resistance of the wheat tan spot fungus.

While fungal MFS transporters were primarily thought to play a role in secretion of toxins $(5,39)$, some MFS transporters have been shown to protect against fungicides. For example, replacement mutants of $B c m f s 1$, a MSF gene from $B$. cinerea, showed increased sensitivity to the natural toxic compounds camptothecin and cercosporin, produced by the plant Camptotheca acuminata and the plant pathogenic fungus Cercospora kikuchii. Transformants overexpressing this gene displayed decreased sensitivity to these compounds and to different fungicides, including azoles. The results indicate that the MSF multidrug transporter $\mathrm{Bcmfs} 1$ is involved in protection against natural toxins and fungicides (21) (Fig. 4).

Taken together, the examples described here show that - in addition to mutations conferring fungicide resistance - efflux-

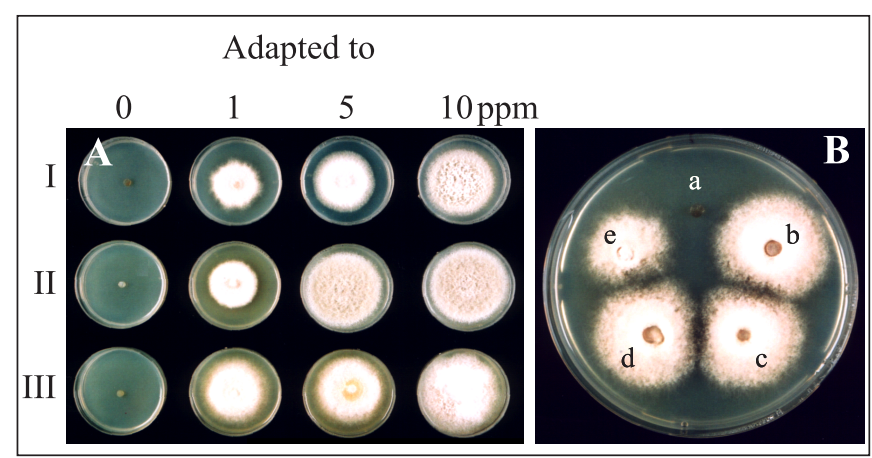

Figure 4: Adaptation of Pyrenophora tritici-repentis to fungicides. Different isolates (Fig. 4A; I, II and III) were allowed to adapt to different concentrations (Fig. 4A; 1, 5 and $10 \mathrm{ppm}$ ) of a strobilurin fungicide and plated out on agar plates containing $50 \mathrm{ppm}$ of the same fungicide. Non-adapted control isolates (Fig. 4A; 0) were unable to grow. Isolates adapted to three different strobilurin fungicides (Fig. 4B; positions b, c and d) and an isolate adapted to an azole fungicide (Fig. 4B; position e) were able to grow on a plate containing $50 \mathrm{ppm}$ of a strobilurin fungicide. A non-adapted control isolate (Fig. 4B; position a) did not grow. 
transporter-mediated quantitative resistance contribute to shifts in fungal populations towards reduced levels of fungicide sensitivity.

Is fungicide resistance in clinical environments related to the occurrence of fungicide resistance in agricultural environments?

Fungicide resistance is not only an agricultural problem, but also in clinical environments pathogenic fungi which are resistant to fungicides have been increasingly reported $(9,57)$. Due to the fact that azole fungicides, which act as sterol biosynthesis inhibitors by blocking C14-demethylation activity, are used in both, agricultural and clinical environments, concerns were raised that fungal species living in both environments may acquire resistance to agricultural azoles in the field, infect humans and may subsequently be difficult to control by medical azole fungicides (23). Indeed, crossresistance to fungicides belonging to the same fungicide class is likely to occur. Aspergillus fumigatus is a human pathogen but it is also a widespread filamentous fungus in the environment and can therefore be exposed to antifungals used in medical and agricultural environments. Without doubt, azoles represent the predominant fungicide class used in both of these environments, and exposure to azoles provides the potential for the development of quantitative resistance. In a drug susceptibility study including 400 clinical and 150 agricultural A. fumigatus isolates, 10 clinical and 36 environmental isolates with resistance to the clinical azole itraconazole were detected (33). However, azole resistance may not only be discussed in the context of "classical" human pathogenic fungi such as $A$. fumigatus, Candida albicans or Cryptococcus neoformans; in recent years several cases of infection of humans by plant pathogenic fungi such as Alternaria alternata or F. oxysporum have been reported $(15,37,43)$. In addition, five Colletotrichum species have been classified as clinically relevant, as they have been reported to infect humans $(6,7,19,36,49)$. All of these pathogens are likely to get in contact with fungicides, and especially with azole fungicides, in agricultural environments. It should be emphasized here that infections by Fusarium, Alternaria or Colletotrichum species occur rarely, and in particular in the case of Colletotrichum specific requirements must be met before an infection can take place. The risk of an infection to occur is increased in immunocompromised patients and in diabetics. In addition, Colletotrichum species require wounded skin in order to infect. On non-wounded skin, germination rates are low, but as soon as traumata occur, conidia germinate, immediately become invasive and rapidly colonize the human tissue. Case reports of Colletotrichum infections of man have been published, and in some cases fungicide resistance of individual isolates have been determined (e.g. 19, 36). Garro et al. (19) analyzed isolates of $C$. dematium, $C$. coccodes, and C. gloeosporioides from diverse sources for their susceptibility to antifungal drugs (amphotericin B, flucytosine, fluconazole, itraconazole, ketoconazole, and miconazole) which belong to different chemical classes and differ in their modes of action. They showed that the majority of isolates displayed a major degree of resistance to one or few fungicides. One isolate of $C$. coccodes was clearly resistant to all of the drugs tested.

On the basis of these considerations and due to the fact that some Colletotrichum species infect plant and human tissue, these species may develop into a model system to investigate and compare infection and fungicide resistance mechanisms in these different hosts.

We have investigated whether Colletotrichum species can adapt to azole fungicide stress and developed a method allowing efficient adaptation to the agricultural azole tebuconazole. As a result, the adapted strains were able to grow efficiently on agar plates containing fungicide concentrations of $30 \mathrm{ppm}$ and above. Fungicide sensitivity assays performed with $C$. graminicola in vitro showed that adaptation to an azole fungicide used in agricultural environments also resulted in resistance to azoles used in clinical environments. Fungicide sensitivity determined by radial growth assays in vitro correlated well with viability staining of fungal hyphae and infection assays with excised human skin (47). It is important to note that some fungicides belonging to classes that do not need to invade the cell to reach their target and to be active, i.g. amphothericin B and nystatin, which form complexes with fungal sterols and induces pore formation, or the $\beta$-1,3-glucan synthase inhibitor caspofungin, were able to control azole-adapted strains more efficiently than non-adapted strains (47).

Currently, the question whether or not extensive application of azole fungicides in agriculture could lead to increased azole resistance and thus cause failure in disease control in clinical environments is debated at the scientific and political level. Fungicide application rates differ significantly in agricultural routine in Europe and the U.S. However, the volume of fungicide application in agriculture did not correlate with the occurrence of fungicide-resistant fungal strains in clinical environments. The lack of correlation suggests that fungicide application in agriculture does not represent a driving force for the development of fungicide resistance in medicine. Statistical studies rather suggest that extensive use of azoles in medicine caused fungicide resistance in fungi attacking humans, and that infections with azole-resistant strains predominantly occur in clinical environments. For detailed discussion, consult the report of the Scientific Steering Committee of the European Commission - Health and Consumer Protection Directory - on azole antimycotic resistance (http://ec.europa.eu/food/fs/sc/ ssc/out278_en.pdf).

Fungicide research with the aim to develop strategies reducing the risk of fungicide resistance to occur is urgently needed in agriculture and in medicine. As mechanisms providing 
Fungicide resistance

the basis for fungicide resistance are likely to be conserved between pathogens of plants and man, plant pathologists and medical microbiologists should develop strategies counteracting the development of fungicide resistance in a concerted action.

\section{Conclusions and recommendations on avoiding or delaying resistance development}

Today, fungicide-based plant protection is indispensable for efficient and large-scale crop production. Importantly, modern fungicides exhibit negligible acute toxicity, and regulations for fungicide application ensure marketing of safe food. As long time periods and enormous financial investments are required to develop new fungicides, care must be taken not to provoke fungicide resistance to occur. This is particularly true, as fungicides with novel modes of action are only rarely found, and resistance to single-target fungicides may occur within few years (Table 1). Today, the key to preventing or at least delaying the onset of the development of fungicide resistance is the composition of efficient fungicide mixtures as well as a change between fungicides with different modes of action during a growing period. The recommendations to maintain highly efficient fungicides at the market include not to use solo-fungicides and not to reduce the rate of fungicides applied below a threshold allowing quantitative resistance to develop. An additional consideration may relate to the screen for future fungicide generations. The philosophy of the last decades was to identify and apply single-target fungicides, which turned out to impose a strong selection pressure for mutants with a modified fungicide-binding site. As fungicides with more than one target are not easily overcome by mutations, the focus in fungicide screens should also be directed to identifying multi-site inhibitors. Having such fungicides available, the risk of rapid occurrence of qualitative resistance could be strongly reduced. Furthermore, considerations on the efficient control of pathogenic microorganisms have been published by Paul Ehrlich almost a century ago and are still valid today. To achieve efficient pathogen control, Ehrlich recommended hitting early and hitting hard (17)! In the light of Ehrlich's recommendation, fungicide reduction programs should be critically evaluated.

\section{ACKNOWLEDGEMENTS}

We thank Dra. Ester Wickert, FCAV/UNESP - Campus de Jaboticabal/SP, Brazil, for critically reading the manuscript and for helpful comments. Financial support of H.B.D's lab by the Ministry of Agriculture and the Ministry of Education of Saxonia-Anhalt, Germany (FKZ: 3205A0020H; FKZ 32852A0080T [EFRE221800100004/50]) and the Deutsche Forschungsgemeinschaft (DFG; DE 403/15-1) is also acknowledged. S. F. P. thanks CNPq for financial support.

\section{RESUMO \\ Mecanismos e significância da resistência a fungicidas}

A ocorrência de resistência a fungicidas é uma das mais importantes conseqüências da agricultura moderna. Este fato pode ser resultado de mutações em genes codificadores de resistência a fungicidas (resistência quantitativa) ou a diferentes mecanismos que são induzidos por stresse devido a doses subletais dos produtos utilizados. Estes mecanismos produzem diferentes e variados níveis de resistência (resistência quantitativa). Também é discutido se o uso extensivo de fungicidas em ambientes agricultáveis é relacionado ou não com a ocorrência de resistência em ambientes clínicos. Além disso, também são fornecidas recomendações de como prevenir ou mesmo retardar o desenvolvimento de resistência a fungicidas em patógenos.

Palavras-chave: mancha preta do citros, manejo de doenças, resistência a fungicidas, bombas de efluxo, doença manchaamarela do trigo, doença mancha-bronzeada do trigo

\section{REFERENCES}

1. Barr, C.M.; Neiman, M.; Taylor, D.R. (2005). Inheritance and recombination of mitochondrial genomes in plants, fungi, and animals. New Phytol., 168: 39-50.

2. Bartels, M. (2000). Leitfaden Pflanzenschutz 2000 - Welche Fungizidstrategien im Weizen 2000? Top Agrar, 1: 51-57.

3. Benato, E.A.; Cia, P. (2007). Controle de doenças pós-colheita: desafios, pesquisa e inovação. Summa Phytopathol., 33: S135137.

4. Benato, E.A.; Cia, P.; Souza, N.L. (2001). Manejo de doenças de frutas pós-colheita. Rev. Anu. Patol. Plantas, 9: 403-440.

5. Callahan, T.M.; Rose, M.S.; Meade, M.J.; Ehrenshaft, M.; Upchurch, R.G. (1999). CFP, the putative cercosporin transporter of Cercospora kikuchii, is required for wild type cercosporin production, resistance, and virulence on soybean. Mol. Plant-Microbe Interact., 12: 901910.

6. Cano, J.; Guarro, J.; Gené, J. (2004). Molecular and morphological identification of Colletotrichum species of clinical interest. J. Clin. Microbiol., 42: 2450-2454.

7. Castro, L.G.; da Silva Lacaz, C.; Guarro, J.; Gene, J.; Heins-Vaccari, E.M.; de Freitas Leite, R.S.; Arriagada, G.L.; Reguera, M.M.; Ito, E.M.; Valente, N.Y.; Nunes, R. (2001). Phaeohyphomycotic cyst caused by Colletotrichum crassipes. J. Clin. Microbiol., 39: 23212324.

8. Chen, C.; Wang, J.; Luo, Q.; Yuan, S.; Zhou, M. (2007). Characterization and fitness of carbendazim-resistant strains of Fusarium graminearum (wheat scab). Pest Manag. Sci., 63: 12011207.

9. Cowen, L.E.; Sanglard, D.; Calabrese, D.; Sirjusingh, C.; Anderson, J.B.; Kohn, L.M. (2000). Evolution of drug resistance in experimental populations of Candida albicans. J. Bacteriol., 182: 1515-1522.

10. Davidse, L.C.; Ishii, H. (1995). Biochemical and molecular aspects of the mechanisms of action of benzimidazoles, $N$-phenylcarbamates and $N$-phenylformamidoximes and the mechanisms of resistance to these compounds in fungi, in Modern Selective Fungicides, Lyr, H., Editor. Gustav Fischer Verlag: New York. p. 305-322. 
11. de Waard, M.A.; Andrade, A.C.; Hayashi, K.; Schoonbeek, H.J.; Stergiopoulos, I.; Zwiers, L.H. (2006). Impact of fungal drug transporters on fungicide sensitivity, multidrug resistance and virulence. Pest Manag. Sci., 62: 195-207.

12. Deising, H.B.; Reimann, S.; Peil, A.; Weber, W.E. (2002). Disease management of rusts and powdery mildews, in The Mycota XI. Application in Agriculture, Kempken, F., Editor. Springer: Berlin. p. 243-269.

13. Del Sorbo, G.; Schoonbeck, H.-j.; De Waard, M.A. (2000). Fungal transporters involved in efflux of natural toxic compounds and fungicides. Fungal Genet. Biol., 30: 1-15.

14. Delp, C.J. (1987). Benzimidazole and related fungicides, in Modern Selective Fungicides - Properties, Applications, Mechanisms of Action, Lyr, H., Editor. Gustav Fischer Verlag: Jena. p. 233-244.

15. Dignani, M.C.; Anaissie, E. (2004). Human fusariosis. Clin. Microbiol. Infect., 10: S67-75.

16. Dixon, R.A. (2001). Natural products and plant disease resistance. Nature, 411: 843-847.

17. Ehrlich, P. (1913). Chemotherapeutics: Scientific principles, methods and results. Lancet, II: 445-451.

18. Forcelini, C.A.; Goellner, C.I.; May-De Mio, L.L. (2001). Resistência de fungos a fungicidas. Rev. Anu. Patol. Plantas, 9: 339-381.

19. Guarro, J.; Svidzinski, T.E.; Zaror, L.; Forjaz, M.H.; Gene, J.; Fischman, O. (1998). Subcutaneous hyalohyphomycosis caused by Colletotrichum gloeosporioides. J. Clin. Microbiol., 36: 3060-3065.

20. Hammerschmidt, R. (1999). Phytoalexins: What have we learned after 60 years? Annu. Rev. Phytopathol., 37: 285-306.

21. Hayashi, K.; Schoonbeek, H.J.; De Waard, M.A. (2002). Bcmfs1, a novel major facilitator superfamily transporter from Botrytis cinerea, provides tolerance towards the natural toxic compounds camptothecin and cercosporin and towards fungicides. Appl. Environ. Microbiol., 68: 4996-5004.

22. Hewitt, H.G. (1998). Fungicides in Crop Protection. Wallingford, UK: CAB International., pp. 221.

23. Hof, H. (2001). Critical annotations to the use of azole antifungals for plant protection. Antimicrob. Agents Chemother, 45: 29872990.

24. Jabs, T.; Cronshaw, K.; Freund, A. (2001). New strobilurin resistance mechanism in apple scab (Venturia inaequalis). Mitt. Deutsch. Phytomed. Ges., 31: 15-16.

25. Kerkenaar, A. (1995). Mechanism of action of cyclic amine fungicides: morpholines and piperidines, in Modern Selective Fungicides, Lyr, H., Editor. Gustav Fischer Verlag: New York. p. 185-204.

26. Kim, Y.-S.; Dixon, E.W.; Vincelli, P.; Farman, M.L. (2003). Field resistance to strobilurin (QoI) fungicides in Pyricularia grisea caused by mutations in the mitochondrial cytochrome $b$ gene. Phytopathology, 93: 891-900.

27. Kislev, M.E. (1982). Stem rust of wheat 3300 years old found in Israel. Science, 216: 993-994.

28. Kontoyiannis, D.P.; Sagar, N.; Hirschi, K.D. (1999). Overexpression of Erg $11 \mathrm{p}$ by the regulatable $G A L 1$ promoter confers fluconazole resistance in Saccharomyces cerevisiae. Antimicrob. Agents Chemother., 43: 2798-2800.

29. Kröcher V.C. (2000). Fit für neue Fungizide im Frühjahr 2000 Erfolgreiche Strategien zur Pilzbekämpfung in Wintergetreide. $d l z$, 1: 34-40.

30. Kuck, K.H.; Scheinpflug, H.; Pontzen, R. (1995). DMI fungicides, in Modern Selective Fungicides, Lyr, H., Editor. Gustav Fischer Verlag: New York. p. 205-258.

31. Lesemann, S.S.; Schimpke, S.; Dunemann, F.; Deising, H.B. (2006). Mitochondrial heteroplasmy for the cytochrome $b$ gene controls the level of strobilurin resistance in the apple powdery mildew fungus Podosphaera leucotricha (Ell. \& Ev.) E.S. Salmon. J. Plant Dis. Protect., 113: 259-266.
32. Löffler, J.; Einsele, H.; Hebart, H.; Schumacher, U.; Hrastnik, C.; Daum, G. (2000). Phospholipid and sterol analysis of plasma membranes of azole-resistant Candida albicans strains. FEMS Microbiol. Lett., 185: 59-63.

33. Meneau, I.; Sanglard, D. (2005). Azole and fungicide resistance in clinical and environmental Aspergillus fumigatus isolates. Med. Mycol., 43: S307-311.

34. Miguez, M.; Reeve, C.; Wood, P.M.; Hollomon, D.W. (2004). Alternative oxidase reduces the sensitivity of Mycospherella graminicola to QOI fungicides. Pest Manag. Sci., 60: 3-7.

35. Moreira, M.A.S.; Souza, E.C.d.; Moraes, C.A.d. (2004). Multidrug efflux systems in Gram-negative bacteria. Brazil. J. Microbiol., 35: $19-28$

36. O'Quinn, R.P.; Hoffmann, J.L.; Boyd, A.S. (2001). Colletotrichum species as emerging opportunistic fungal pathogens: a report of 3 cases of phaeohyphomycosis and review. J. Am. Acad. Dermatol., 45: $56-61$.

37. Ortoneda, M.; Guarro, J.; Madrid, M.P.; Caracuel, Z.; Roncero, M.I.; Mayayo, E.; Di Pietro, A. (2004). Fusarium oxysporum as a multihost model for the genetic dissection of fungal virulence in plants and mammals. Infect. Immun., 72: 1760-1766.

38. Pao, S.S.; Paulsen, I.T.; Saier, M.H.J. (1996). Major facilitator superfamily. Microbiol. Mol. Biol. Rev., 62: 1-34.

39. Pitkin, J.W.; Panaccione, D.G.; Walton, J.D. (1996). A putative cyclic peptide efflux pump encoded by the TOXA gene of the plant pathogenic fungus Cochliobolus carbonum. Microbiology, 142: 15571565.

40. Pommer, E.-H. (1995). Morpholine fungicides and related compounds, in Modern Selective Fungicides, Lyr, H., Editor. Gustav Fischer Verlag: New York. p. 163-183.

41. Reimann, S.; Deising, H.B. (2005). Inhibition of efflux transportermediated fungicide resistance in Pyrenophora tritici-repentis by a derivative of natural 4'-hydroxyflavone and potentiation of fungicide activity. Appl. Environ. Microbiol., 71: 3269-3275.

42. Rodrigues, M.B.C. (2006). Controle de Guignardia citricarpa, agente causal da mancha preta dos citros. Dissertação de Mestrado in Genética e Melhoramento de Plantas. Esalq/USP: Piracicaba, SP.

43. Sasama, J.; Sherris, D.A.; Shin, S.H.; Kephart, G.M.; Kern, E.B.; Ponikau, J.U. (2005). New paradigm for the roles of fungi and eosinophils in chronic rhinosinusitis. Curr. Opinion. Otolaryng. Head Neck Surg., 13: 2-8, 2005.

44. Saurin, W.; Hofnung, M.; Dassa, E. (1999). Getting in or out: Early segregation between importers and exporters in the evolution of ATP-binding cassette (ABC) transporters. J. Mol. Evol., 48: 2241.

45. Schnabel, G.; Jones, A.L. (2001). The 14 $\alpha$-demethylase (CYP51A1) gene is overexpressed in Venturia inaequalis strains resistant to myclobutanil. Phytopathology, 91: 102-110.

46. Schroeder, W.T.; Provvidenti, R. (1969). Resistance to benomyl in powdery mildew of cucurbits. Plant Dis. Rep., 53: 271-275.

47. Serfling, A.; Wohlrab, J.; Deising, H.B. (2007). Treatment of a clinically relevant plant pathogenic fungus with an agricultural azole causes cross-resistance to medical azoles and potentiates caspofungin efficacy. Antimicrob. Agents Chemother, 51: 3672-3676.

48. Sherwood, J.E.; Somerville, S.C. (1990). Sequence of the Erysiphe graminis f. sp. hordei gene encoding b-tubulin. Nucl. Acids Res., 18: 1052.

49. Shukla, P.K.; Khan, Z.A.; Lal, B.; Agrawal, P.K.; Srivastava, O.P. (1983). Clinical and experimental keratitis caused by the Colletotrichum state of Glomerella cingulata and Acrophialophora fusispora. Sabouraudia, 21: 137-147.

50. Sierotzki, H.; Wullschleger, J.; Gisi, U. (2000). Point mutation in cytochrome $\mathrm{b}$ gene conferring resistance to strobilurin fungicides in Erysiphe graminis f. sp. tritici field isolates. Pest. Biochem. Physiol., 68: $107-112$. 
51. Snyder, B.A.; Nicholson, R.L. (1990). Synthesis of phytoalexins in sorghum as a site-specific response to fungal ingress. Science, 248: 1637-1639.

52. Steinfeld, U.; Sierotzki, H.; Parisi, S.; Poirey, S.; Gisi, U. (2001). Sensitivity of mitochondrial respiration to different inhibitors in Venturia inaequalis. Pest Manag. Sci., 57: 787-796.

53. Taglicht, D.; Michaelis, S. (1998). Saccharomyces cerevisiae ABC proteins and their relevance to human health and disease. Meth Enzymol, 292: 130-162.

54. Toffano, L. (2005). Doenças pós-colheita em citros: potencial do Lentinula edodes, Agaricus blazei, ácido jasmônico, albedo (Citrus sinensis var. Valência) e flavedo (Citrus aurantifolia var. Tahiti) no controle e na indução de resistência. Master's Dissertation in Plant Pathology. Esalq/USP: Piracicaba, SP.

55. Urban, M.; Bhargava, T.; Hamer, J.E. (1999). An ATP-driven efflux pump is a novel pathogenicity factor in rice blast disease. EMBO J., 18: $512-521$.
56. Walker, J.E.; Saraste, M.; Runswick, M.J.; Gay, N.J. (1982). Distantly related sequences in the alpha- and beta-subunits of ATP synthase, myosin, kinases and other ATP-requiring enzymes and a common nucleotide binding fold. EMBO J., 1: 945-951.

57. White, T.C.; Holleman, S.; Dy, F.; Mirels, L.F.; Stevens, D.A. (2002). Resistance mechanisms in clinical isolates of Candida albicans. Antimicrob. Agents Chemother, 46: 1704-1713.

58. Ziogas, B.N.; Baldwin, B.C.; Young, J.E. (1997). Alternative respiration: a biochemical mechanism of resistance to azoxistrobin (ICIA 5504) in Septoria tritici. Pest. Sci., 50: 28-34.

59. Zwiers, L.H.; Stergiopoulos, I.; Gielkens, M.M.; Goodall, S.D.; De Waard, M.A. (2003). ABC transporters of the wheat pathogen Mycosphaerella graminicola function as protectants against biotic and xenobiotic toxic compounds. Mol. Genet. Genom., 269: 499507 . 